Л.Ф. Купченко, Г.В. Худов, А.П. Гурін, А.С. Риб'як

Харківський національний університет Повітряних Сил ім. І. Кожедуба, Харків

\title{
АКТИВНА ОПТИКО-ЕЛЕКТРОННА СИСТЕМА ВИЯВЛЕННЯ ЗАТІНЕНИХ ОБ'ЄКТІВ, ЯКА ВИКОРИСТОВУЄ ПРИНЦИПИ СПЕКТРАЛЬНОЇ УЗГОДЖЕНОЇ ДИНАМІЧНОЇ ОБРОБКИ ЗОБРАЖЕНЬ
}

В статті розглядаються принцчипи побудови бортової авіаційної системи виявлення затінених об'єктів на основі активної оптико-електронної системи з динамічною узгодженою спектральною обробкою оптичного випромінювання, у якій джерелом випромінювання є набір багатоспектральних лазерних випромінювачів. На підставі апріорних даних щодо спектральних характеристик об'єкту та фону розраховується управляючий сигнал для зміни яскравості випромінювання системи лазерних випромінювачів, таким чином, щуоб зменшити величину спектральних складових сигналу відбитого від поверхні, щчо належить фону, з мінімальним ослабленням інтенсивності сигналу, відбитого від об'єкту. Розроблена математична модель, яка дозволяє оцінити ефективність активної оптико-електронної системи за величиною контрасту затінених об'єктів.

Ключові слова: активна оптико-електронна система, спектральна обробка оптичного випромінювання, виявлення затінених об'єктів.

\section{Вступ}

Постановка проблеми. Найбільш розповсюдженими задачами, які розв'язуються оптикоелектронними системами, є виявлення, розпізнавання та класифікація об'єктів. Під час розв'язання такого класу задач використовують певний опис образів (сукупність сигналів, що обробляються), які складають відмінні ознаки об'єктів. Найчастіше використовують такі групи ознак: геометричні ознаки, спектральні, енергетичні та динамічні.

За принципом формування інформаційних полів (полів випромінювання) усі оптико-електронні системи розподіляються на пасивні та активні. Пасивні оптико-електронні системи використовують інформаційні поля, що формуються природним випромінюванням в просторі об'єктів. Активний метод побудови оптико-електронних систем передбачає створення інформаційного поля 3 використанням штучних джерел випромінювання.

Стаття присвячена розробці активної оптикоелектронної системи, яка грунтується на принципах спектральної обробки зображень та забезпечує виявлення затінених об'єктів за допомогою підвищення контрасту зображення об'єкту з використанням принципів спектральної узгодженої динамічної обробки.

Аналіз останніх досліджень і публікацій. Фізична основа побудови активних оптико-електронних систем з узгодженою обробкою оптичних сигналів грунтується на тому, що кольорові поверхні мають вибіркову здатність відбивати та поглинати світло різних довжин хвиль. Якщо поверхня здатна відбивати промені червоного кольору, то при освітленні його зеленим світлом поверхня нічого відбивати не буде та буде чорною [1, с. 94].
Вибір спектральних ознак обумовлений тим, що під час спектральної обробки відсутня необхідність високої просторової роздільної здатності, тому що розпізнавання може проводитися за одним пікселем [2, с. 79].

Також слід зазначити, що при використанні геометричних ознак необхідно мати високу просторову роздільну здатність i, отже, велику приймальну апертуру приймальної частини оптико-електронної системи, що призводить до зниження відношення сигнал-шум системи виявлення [3, с. 22-26].

Виявленню затінених об’єктів присвячена робота [4, с. 1-23], у якій обговорюється принцип створення оптико-електронної системи для обладнання безпілотного літального апарату, призначеного для виявлення та розпізнавання цілей під деревами. Метод грунтується на тому, що об'єкт, який знаходиться під деревами, реєструється під різними ракурсами, а потім отримані тривимірні зображення під час електронної обробки “склеюють”. Під час формування зображення використовуються геометричні ознаки. Для цього до складу оптикоелектронної системи доданий радар зі спалахом, який сканує та підраховує фотони.

Виявленню прихованих об'єктів присвячена робота [5, с. 144-153], у якій продемонстрована ефективність використання системи активної гіперспектральної візуалізації для виявлення та ідентифікації цілей $з$ найменшими помилками, яка складається 3 освітлювача на основі мікролазера та скануючого спектрометру.

Мета статті - розробка принципів побудови авіаційної активної оптико-електронної системи виявлення затіненої цілі з динамічною узгодженою спектральною обробкою оптичного випромінюван- 
ня, яка забезпечує підвищення контрасту цілі відносно фону, а також розробка математичної моделі, що дозволяє оцінити ефективність системи.

\section{Виклад основного матеріалу}

1. Основи побудови активної оптикоелектронної системи 3 динамічною спектральною обробкою.

При розв'язанні задач оптимального прийому зазвичай використовують методи математичної статистики і формулюють задачу наступним чином. Апріорно повинні бути відомі статистичні характеристики корисного сигналу та завад, - необхідно розробити пристрій, який найкращим чином може приймати рішення про виявлення об'єкту 3 мінімальними помилками [6, с. 4-5].

У роботі [7, с. 489-492] розроблені принципи побудови активної оптико-електронної системи 3 динамічною спектральною обробкою, у якій джерелом випромінювання $є$ набір багатоспектральних лазерних випромінювачів. Для підвищення контрасту зображення використовуються апріорні відомості щодо спектральних характеристик об'єкту та фону.

У відповідності до апріорних відомостей розраховується управляючий сигнал для зміни яскравості випромінювання системи лазерних випромінювачів таким чином, щоб зменшити величину спектральних складових сигналу відбитого від поверхні, яка належить до фону, з мінімальним послабленням інтенсивності сигналу відбитого від об'єкту.

Покажемо, що сигнал, який реєструється приймачем випромінювання активної оптикоелектронної системи, являє собою результат розрахунку скалярного добутку вектору $\vec{X}$, що відповідає потоку випромінювання, відбитого від об'єкту, на вектор апаратної функції (ваговий вектор) передаючої частини активної оптико-електронної системи $\vec{F}$.

Для цього використаємо результати роботи [8, с. 218-226], у якій зазначено, від яких параметрів системи залежить потік випромінювання $\Phi_{e}$, що надходить до приймача випромінювання системи. Нехай багатоспектральне джерело випромінювання має спектральну яскравість $L_{\Sigma e}(\lambda)$ та спрямовує світловий потік на об'єкт, який знаходиться на відстані $l_{1}$ від оптико-електронної системи. Частина потоку, відбитого від об'єкту, потрапляє до вхідної зіниці приймальної частини оптико-електронної системи, що знаходиться на відстані $l_{2}$ від об'єкту. При умові рівності $l_{1}=l_{2}=1$ та круглих вихідній та вхідній зіницях передаючої та приймальної частин системи, а також при дифузному характері відбиття поверхні об'єкта світловий потік на вході приймача випромінювання може бути представлений в такому вигляді:

$$
\begin{aligned}
& \Phi_{e}=\frac{\pi D^{2}{ }_{B u x} D^{2}{ }_{B x} A_{2}}{16 l^{4}} . \\
& \cdot \int_{\lambda_{1}}^{\lambda_{2}} L_{\Sigma e}(\lambda) \tau_{o 1}(\lambda) \tau_{c}^{2}(\lambda) \rho(\lambda) \tau_{o 2}(\lambda) d \lambda,
\end{aligned}
$$

де $A_{2}$ - видима з вхідної зіниці площа відбиття поверхні об'єкта; $\tau_{c}(\lambda)$ - спектральний коефіцієнт пропускання середовища; $D_{\text {вих }}$ - діаметр вихідної зіниці передаючої частини АOEC; $D_{b x}$ - діаметр вхідної зіниці приймальної частини АOEC; $\tau_{o 1}(\lambda)-$ спектральний коефіцієнт пропускання оптичної підсистеми передаючої частини; $\tau_{o 1}(\lambda)$ - спектральний коефіцієнт пропускання оптичної підсистеми приймальної частини; $\rho(\lambda)$ - спектральний коефіцієнт відбиття об'єкта.

Нехай спектральна яскравість джерела випромінювання передаючої частини $L_{\Sigma e}(\lambda)$ формується у вигляді суми $m$ монохроматичних випромінювачів зі спектральними яскравостями $L_{e k}(\lambda)$ :

$$
L_{\Sigma e}(\lambda)=\sum_{k=1}^{m} L_{e k}(\lambda)=\sum_{k=1}^{m} A_{k} \varphi_{e k}(\lambda),
$$

де $\varphi_{e k}(\lambda)$ - відносна спектральна яскравість $k$-го джерела; $A_{k}$ - максимальне значення спектральної яскравості $k$-го джерела випромінювання.

Підставивши (2) в (1) та врахувавши, що в (2) спектральна яскравість є сумою кінцевої кількості монохроматичних складових, отримаємо

$$
\begin{aligned}
& \Phi_{e}=q \sum_{k=1}^{m} A_{k} \int_{\lambda_{1}}^{\lambda_{2}} \varphi_{e k}(\lambda) \tau_{01}(\lambda) \tau_{c}^{2}(\lambda) \rho(\lambda) \tau_{02}(\lambda) d \lambda= \\
& =q \sum_{k=1}^{m} f_{k} x_{k} \cong \vec{F}^{T} \vec{X}
\end{aligned}
$$

де $q=\frac{\pi D^{2}{ }_{\text {виx }} D^{2}{ }_{\text {вx }} A_{2}}{16 l^{4}}-$ складова, що залежить від конструктивних параметрів АОЕС та умов її роботи; $\vec{F}=\left[f_{1}, \ldots f_{k}, \ldots f_{m}\right]^{T}-$ вектор апаратної функції передаючої частини АОЕС (вектор вагової обробки), координати якого складають основу максимальних значень інтенсивності для кожної монохроматичної складової джерела випромінювання, $f_{k}=A_{k}$; $\vec{X}=\left[x_{1}, \ldots x_{k}, \ldots x_{m}\right]^{T}-$ вектор вхідного оптичного сигналу, координати якого визначаються наступним чином: 


$$
x_{k}=\int_{\lambda_{1}}^{\lambda_{2}} \varphi_{e k}(\lambda) \tau_{o 1}(\lambda) \tau_{c}^{2}(\lambda) \rho(\lambda) \tau_{o 2}(\lambda) d \lambda .
$$

Таким чином, потік $\Phi_{e}$, що надходить на вхід приймача випромінювання активної оптикоелектронної системи 3 динамічною спектральною обробкою, буде визначатися скалярним добутком вектора $\vec{X}$, що відповідає потоку випромінювання, відбитого від об'єкту, на вектор апаратної функції (ваговий вектор) передаючої частини оптикоелектронної системи $\vec{F}$.

Зазначені вище основи динамічної спектральної обробки оптичного випромінювання в активних оптико-електронних системах дозволяють розробити функціональну та структурну схеми активної оптико-електронної системи.

На рис. 1 зображена структурна схема оптимального узгодженого фільтру.

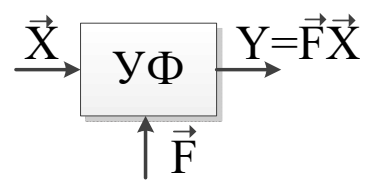

Рис. 1. Структурна схема оптимального узгодженого фільтру Джерело: [2, с. 98].

На рис. 2 зображена функціональна схема, яка пояснює принципи формування оптичних сигналів в активній оптико-електронній системі 3 динамічною спектральною фільтрацією.

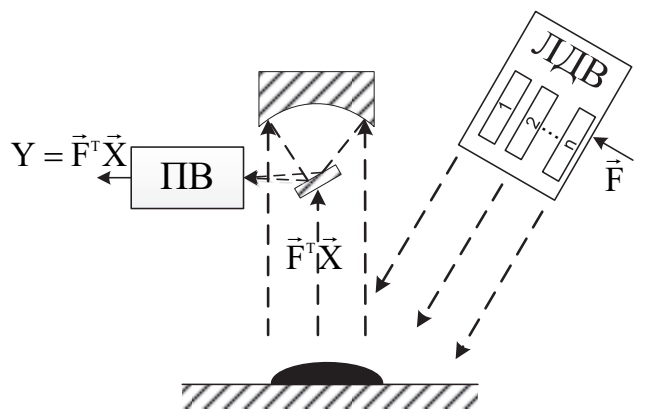

Рис. 2. Функціональна схема формування оптичних сигналів в активній оптико-електронній системі

3 динамічною спектральною обробкою

(ПВ - приймач випромінювання;

ЛДВ - лазерне джерело випромінювання) Джерело: [8, с. 221].

Робота присвячена розробці принципів побудови активних оптико-електронних систем 3 динамічною спектральною обробкою, в яких використовуються лазерні багатоспектральні зондуючі сигнали. Спектральний склад зондуючого випромінювання формується таким чином, щоб на виході оптикоелектронної системи формувався мінімальний відгук для випромінювання, відбитого від фону, та ма- ксимальний відгук для випромінювання, відбитого від поверхні об'єкту.

2. Алгоритм розрахунку управляючого сигналу оптико-електронної системи 3 динамічною спектральною обробкою оптичних сигналів.

Активну оптико-електронну систему з динамічною спектральною обробкою можна розглядати як аналогову оптичну обчислювальну систему. Переходячи до фізичної реалізації оптико-електронних систем 3 динамічною фільтрацією, зазначимо, що в аналогових оптичних обчислювачах основними математичними операціями над оптичними сигналами $€$ складання та множення. Операція складання реалізується шляхом суміщення в одній точці декількох світлових променів, в тому числі за допомогою лінзи, а операція множення реалізується або за допомогою оптичних елементів з управляючою прозорістю, або елементів 3 управляємим коефіцієнтом відбиття [8, c. 218-226].
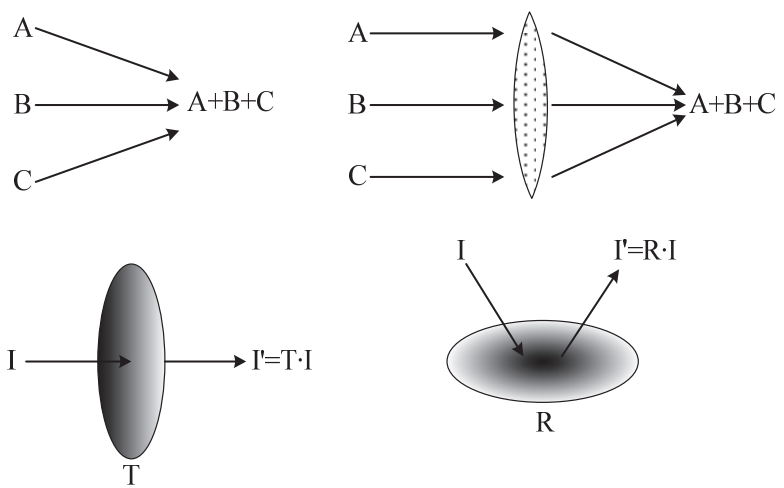

Рис. 3. Основні математичні операції над оптичними сигналами

Джерело: [8, с. 219].

В активних системах 3 динамічною спектральною фільтрацією в операції множення приймають участь два співмножника. Один зі співмножників це спектральний коефіцієнт відбиття зондуючої поверхні з апріорно відомими спектральними характеристиками, а другий співмножник - лазерний багатоспектральний сигнал, спектральна щільність яскравості якого формується таким чином, щоб забезпечити на виході приймача оптико-електронної системи мінімальний відгук для випромінювання, відбитого від фону, і максимальний відгук для випромінювання, відбитого від поверхні об'єкту.

В активній системі зондуючий поліхроматичний сигнал формується у вигляді суми монохроматичних лазерних сигналів, тому оптичне випромінювання, яке відбивається від об'єкту і фону, може бути представлено у вигляді векторів в багатомірному спектральному просторі. При цьому процес спектральної фільтрації оптичного випромінювання може бути досліджений з використанням векторного подання сигналів. 
Математичною основою динамічної спектральної фільтрації є операція розрахунку скалярного добутку. Для спектральної фільтрації випромінювання однорідного об'єкту на однорідному фоні підвищення контрасту зображення цілі забезпечується визначенням такого вектору апаратної функції $\vec{F}$, скалярний добуток якого з вектором фону $\vec{B}$ буде дорівнювати нулю, а добуток 3 вектором об'єкту буде максимальним (рис. 4). При цьому координати $f_{i}$ вектора фільтру $\vec{F}_{H}=\left\|f_{i}\right\|$ відповідають відносним інтенсивностям монохроматичних складових лазерного випромінювання.

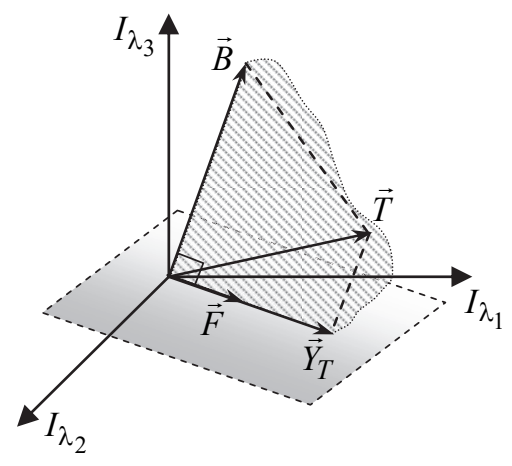

Рис. 4. Ілюстрація до динамічної спектральної фільтрації випромінювання однорідного об'єкту на однорідному фоні Джерело: [9, с. 359].

Для випадку динамічної спектральної фільтрації випромінювання однорідного об'єкту на однорідному фоні апаратна функція розраховується на основі апріорних даних спектральних характеристик вектора об'єкту $\vec{T}$ і вектора фону $\vec{B}$ з використанням наступного виразу [10, с. 35$]$ :

$$
\vec{F}=\frac{\vec{T}-N \cdot \vec{B}}{\|\vec{T}-N \cdot \vec{B}\|}
$$

де $N=\frac{\vec{T}^{T} \cdot \vec{B}}{\vec{B}^{T} \cdot \vec{B}}-$ проекція вектора об'єкту на вектор фону.

На рис. 4 в тривимірному просторі зображено розташування векторів при спектральній фільтрації. Вектор апаратної функції $\vec{F}=f_{1} \vec{\lambda}_{1}+f_{2} \vec{\lambda}_{2}+f_{3} \vec{\lambda}_{3} \epsilon$ ортогональним до вектора фону $\vec{B}=b_{1} \vec{\lambda}_{1}+b_{2} \vec{\lambda}_{2}+b_{3} \vec{\lambda}_{3}$, та лежить в площині, яка створена вектором $\vec{B}$ і вектором, що ілюструє спектральні властивості об'єкту $\vec{T}=t_{1} \vec{\lambda}_{1}+t_{2} \vec{\lambda}_{2}+t_{3} \vec{\lambda}_{3}$.

$\mathrm{B}$ алгебраїчній формі скалярний добуток являє собою операцію множення проекцій векторів, які приймають участь у процесі селекції з подальшим їх підсумовуванням. У випадку, який надається, скалярний добуток ортогональних векторів фону та апаратної функції дорівнює нулю, а скалярний добуток вектора об'єкту та апаратної функції відмінний від нуля

$$
(\vec{T} \cdot \vec{F})=t_{1} f_{1}+t_{2} f_{2}+t_{3} f_{3} \neq 0
$$

та характеризує величину сигналу на виході приймача оптико-електронної системи.

На рис. 5 зображена структурна схема активної оптико-електронної системи 3 динамічною спектральною фільтрацією, яка складається $з$ передавальної та приймальної частин. Передавальна частина активної оптико-електронної системи складається 3: формувача апаратної функції (1), бібліотеки спектральних характеристик (2); лазерного блоку (3), формувача багатоспектрального лазерного пучка (4). До приймальної частини системи входять: об'єктив (5), приймач випромінювання (6), електронний блок обробки (7).

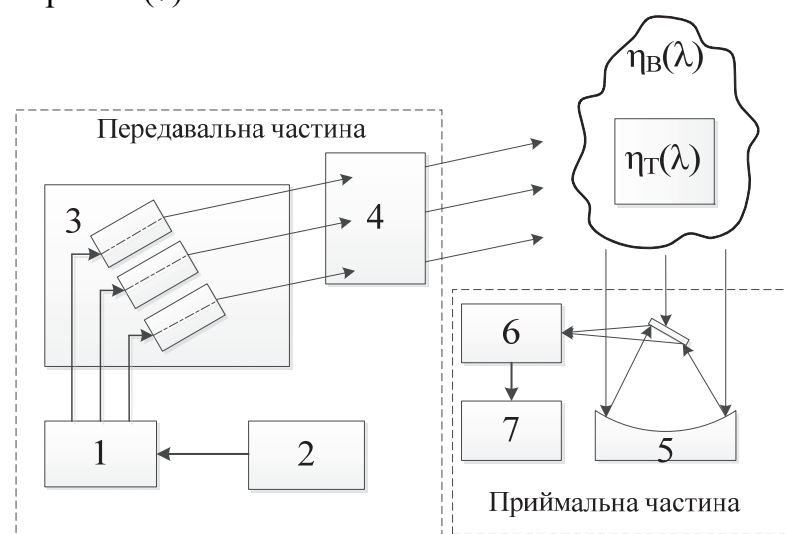

Рис. 5. Структурна схема активної оптикоелектронної системи 3 динамічною узгодженою спектральною фільтрацією Джерело: [8, с. 222].

Формувач апаратної функції призначений для створення на основі апріорних спектральних характеристик об'єкту та фону управляючого сигналу, який забезпечує на виході лазерного блоку багатоспектральне випромінювання з необхідною спектральною щільністю. Лазерний блок складається 3 набору лазерів, які працюють в одномодовому режимі і генерують монохроматичне випромінювання.

Формувач багатоспектрального лазерного пучка призначений для створення з набору монохроматичних лазерних сигналів поліхроматичного випромінювання та управління його кутовою розбіжністю.

В приймальній частині оптико-електронної системи відбите від зондуючої поверхні поліхроматичне оптичне випромінювання перетворюється в електричні сигнали приймачем випромінювання та реєструється в електронному блоці обробки.

3. Математична модель виявлення затінених об'єктів 3 використанням активної оптикоелектронної системи 3 динамічною узгодженою спектральною обробкою оптичного випромінювання. 
Метою математичного моделювання було, щоб при фіксованих значеннях спектральних характеристик об'єкту та фону визначити, як змінюється контраст об'єкту в залежності від величини затінення об'єкту.

Основу спектральної узгодженої динамічної обробки зображення складають наступні положення.

По-перше, передбачається, що в результаті реєстрації випромінювання деякого предметного простору формується повнокольорове цифрове RGB зображення.

По-друге, відповідно до кольорової моделі RGB кожен елемент вихідного кольорового зображення $з$ координатами $(i, j)$ представляється у вигляді вектору $\vec{X}_{i, j}=\left[x_{R}(i, j), x_{G}(i, j), x_{B}(i, j)\right]^{T}$ в тривимірному евклідовому просторі, де $x_{R}, x_{G}, x_{B}$ - значення яскравості, які виміряні в червоному (R-red), зеленому (G-green) та синьому (B-blue) спектральних каналах [11, с. 76].

По-третє, передбачається, що нам відомі апріорні дані щодо числових параметрів імовірнісних характеристик сигналів об’єкту та фону (вектор математичного очікування та кореляційна матриця) або маються репрезентативні вибірки, які дозволяють оцінити їх за допомогою наступних співвідношень [12, с. 59-60]:

$$
\begin{gathered}
\vec{\mu}=E[\vec{X}]=\frac{1}{r} \sum_{\xi=1}^{r} \vec{X}_{\xi} ; \\
\Gamma=E\left[(\vec{X}-\vec{\mu})(\vec{X}-\vec{\mu})^{T}\right]=\frac{1}{r-1} \sum_{\xi=1}^{r}\left(\vec{X}_{\xi}-\vec{\mu}\right)\left(\vec{X}_{\xi}-\vec{\mu}\right)^{T},
\end{gathered}
$$

де $\vec{X}$ - тривимірний вектор $\xi$-го елементу репрезентативної вибірки об'єкту спостереження або фону; $r$ - кількість елементів репрезентативної вибірки об’єкту або фону.

Та, нарешті, по-четверте, передбачається, що процес спектральної фільтрації полягає в обчисленні скалярного добутку векторів елементу вихідного кольорового зображення $\vec{X}$ та фільтру $\vec{F}$.

Відповідно до цих положень алгоритм цифрової обробки кольорових зображень складається 3 таких етапів:

- під час першого етапу, використовуючи числові параметри спектральних характеристик сигналів об'єкту та фону, визначається вектор фільтру $\vec{F}$, який забезпечує підвищення контрасту об'єкта;

- під час другого етапу обчислюється скалярний добуток векторів елемента вихідного кольорового зображення $\vec{X}$ та фільтру $\vec{F}$;

- на заключному етапі проводиться (при необхідності) приведення отриманого в результаті обробки зображення до вигляду, який є зручним для візуального сприйняття, що передбачає порогову обробку отриманого зображення.

Обробці піддавалося кольорове зображення лісового масиву, отримане с літального апарату в простих метеоумовах за допомогою цифрового фотоапарату, яке містить $1168 \times 1135$ елементів роздільної здатності. На знімку (рис. 6, а) зображено лісовий масив 3 розташованим на ньому незатіненим танком, а поруч представлене зображення (рис. 6, б), яке піддано цифровій обробці з метою підвищення контрасту.
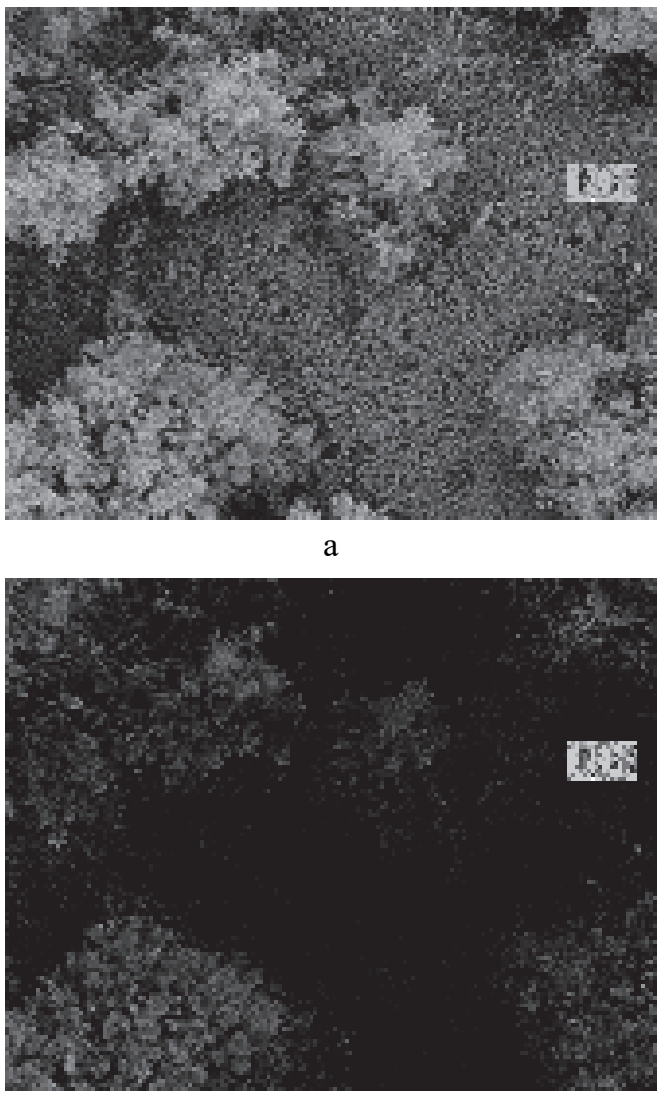

6

Рис. 6. Результати цифрової обробки (затінення об'єкту відсутнє):

a - зображення до обробки; б - зображення після підвищення контрасту об'єкта. Контраст до обробки

$-K_{b x}=0,351$, після обробки $-K_{\text {вих }}=0,895$

Джерело: розроблено авторами.

Якість цифрової обробки зображення, яка на відміну від виразу (5) (де розглядається участь однорідного об'єкту на однорідному фоні), оцінювалася шляхом розрахунку контрасту до цифрової обробки $K_{b x}$ та після обробки $K_{6 u x} 3$ використанням наступних співвідношень [8, с. 40]:

$$
K_{b x}=\frac{\vec{F}_{1}^{T}\left(\vec{\mu}_{o}-\vec{\mu}_{\phi}\right)}{\vec{F}_{1}^{T}\left(\vec{\mu}_{o}+\vec{\mu}_{\phi}\right)},
$$

де $\vec{F}_{1}=\left[\begin{array}{lll}1 & 1 & 1\end{array}\right]^{T}$ - вектор фільтру, який забезпечує мінімальне послаблення вхідного випромінювання 
селектуючим пристроєм; де $\vec{\mu}_{o}, \vec{\mu}_{\phi}$ - математичні очікування сигналів об'єкту та фону до цифрової обробки;

$$
K_{\text {bux }}=\frac{\mu_{o}-\mu_{\phi}}{\mu_{o}+\mu_{\phi}}
$$

де $\mu_{o}, \mu_{\phi}-$ математичні очікування сигналів об’єкту та фону після цифрової обробки.

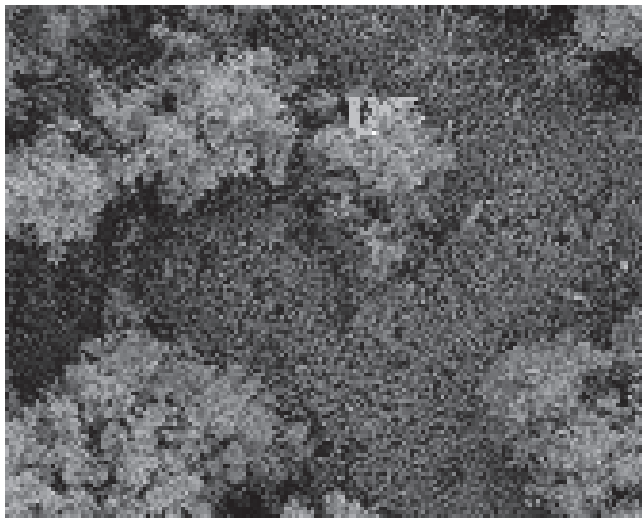

a

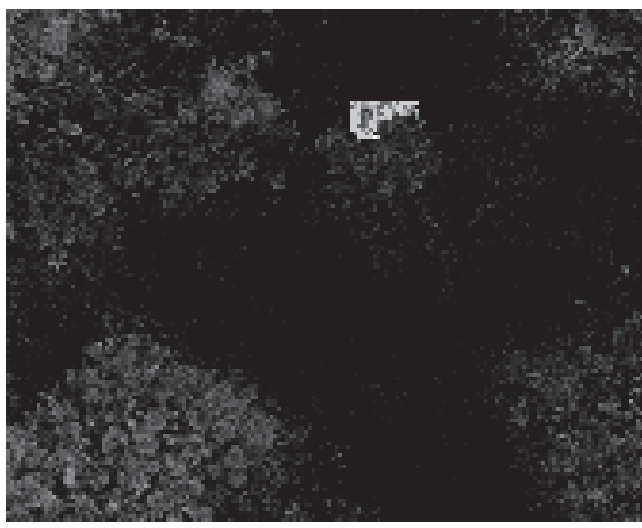

6

Рис. 7. Результати цифрової обробки

(затінення об'єкту складає 25\%):

$\mathrm{a}$ - зображення до обробки; б - зображення після підвищення контрасту об' єкта. Контраст до обробки $-K_{B x}=0,283$, після обробки $-K_{\text {вux }}=0,865$

Джерело: розроблено авторами.

Розрахунок значень контрасту об'єкту 3 використанням виразів (9) та (10) для зображень (рис. 6) дозволив отримати наступні результати: величина контрасту об'єкту на вихідному зображенні (рис. 6, а) складає $K_{b x}=0,351$, а при використанні цифрової обробки зображень контраст об'єкту (рис. 6, б) складає $K_{\text {вих }}=0,895$.

Далі проводилася цифрова обробка зображення при різній величині затінення об'єкту лісовою рослинністю, та обчислювалися кількісні характеристики контрасту. На рисунках показано різну величину затінення розміру об'єкту (рис. 7 - затінення виконано на $25 \%$; рис. 8 - затінення виконано на $50 \%$; рис. 9 - затінення виконано на 75\%).

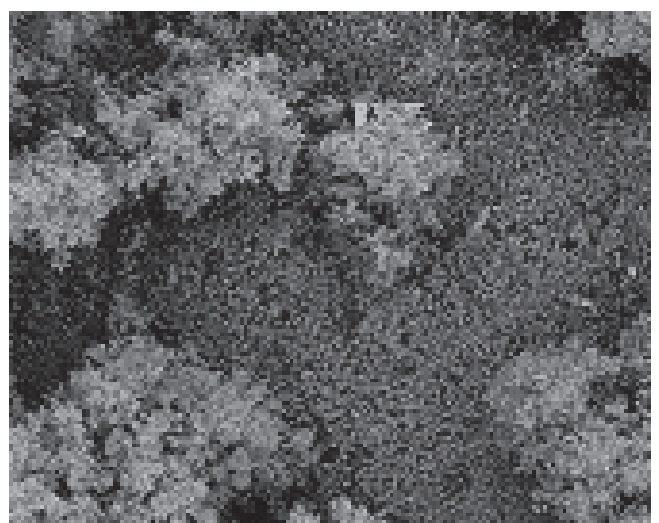

a

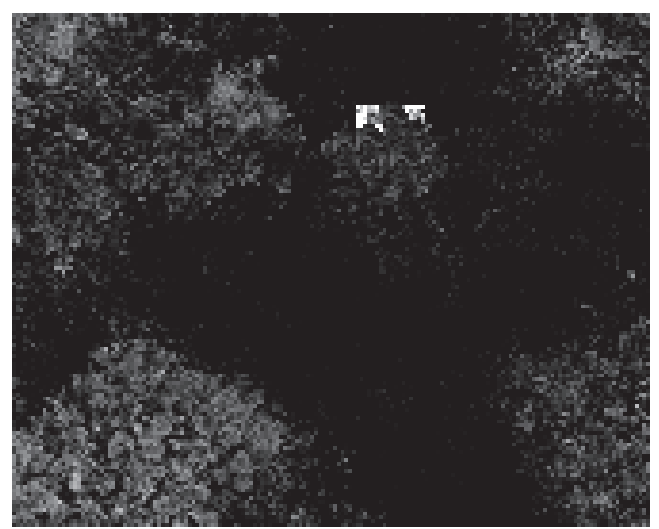

6

Рис. 8. Результати цифрової обробки (затінення об'єкту складає 50\%)

a - зображення до обробки; б - зображення після підвищення контрасту об' єкта. Контраст до обробки $-K_{b x}=0,23$, після обробки $-K_{6 u x}=0,791$

Джерело: розроблено авторами.

Слід відмітити, що всі елементи зображень не затінених листям, спектральні характеристики яких відповідають властивостям об'єкту, мають підвищену яскравість. Крім цього спостерігаються флуктуації яскравості фону, що обумовлено, напевно, тим, що спектральні характеристики окремих ділянок лісового масиву співпадають 3 спектральними властивостями об'єкту.

На рис. 10 представлений графік, що ілюструє зміни контрасту об’єкту від величини поверхні об'єкту, яка спостерігається (незатінена). Контраст до фільтрації зображення $K_{B x}$ позначено пунктирною лінією. Контраст після фільтрації зображення $K_{\text {вих }}$ позначено суцільною лінією. Як випливає 3 графіку, зі зменшенням величини поверхні об'єкту, яка спостерігається, величина контрасту зменшується, що, напевно, пов'язано зі зменшенням кількості пікселів, які приймають участь у формуванні поверхні відбиття об'єкту.

Таким чином, використання математичного моделювання активної оптико-електронної системи 3 динамічною узгодженою спектральною обробкою оптичного випромінювання, яка забезпечує вияв- 
лення затінених об'єктів спостереження, дозволило збільшити контраст між сигналом об'єкту та сигналом фону в 2,5 рази.

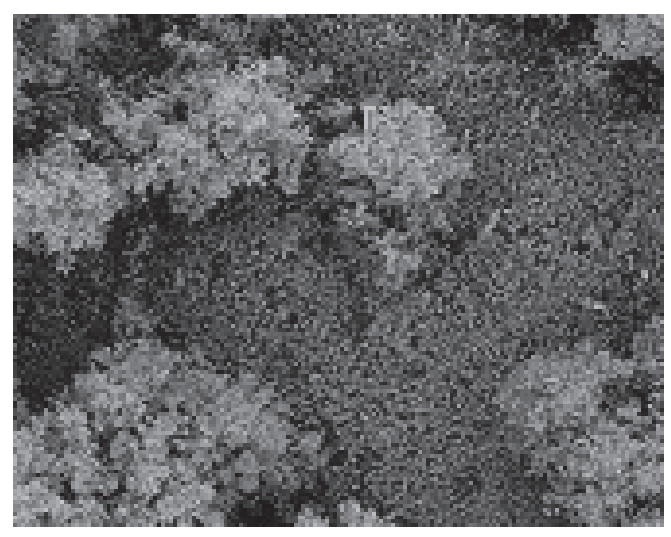

a

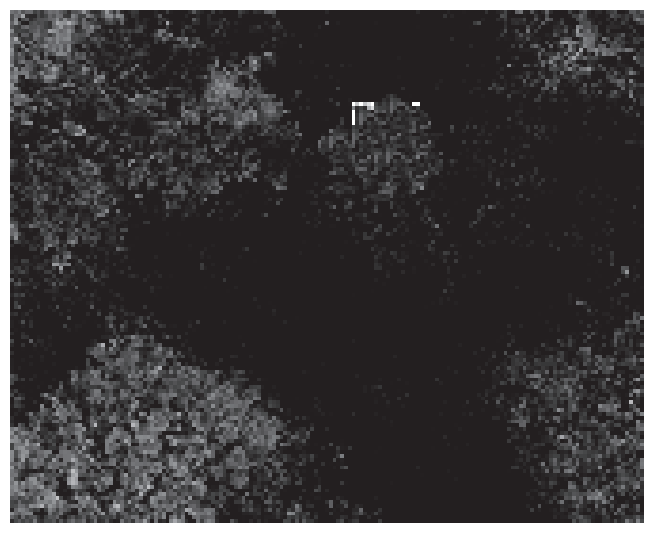

б

Рис. 9. Результати цифрової обробки ( затінення об'єкту складає 75\% )

$\mathrm{a}$ - зображення до обробки; б - зображення після підвищення контрасту об'єкта. Контраст до обробки

$-K_{b x}=0,2$, після обробки $-K_{\text {виx }}=0,701$

Джерело: розроблено авторами.

\section{Висновки}

Розроблена активна оптико-електронна система 3 використанням принципів спектральної обробки зображень, що дозволяє забезпечити виявлення за тінених об'єктів, коли відомості щодо геометричних ознак об’єкту відсутні.

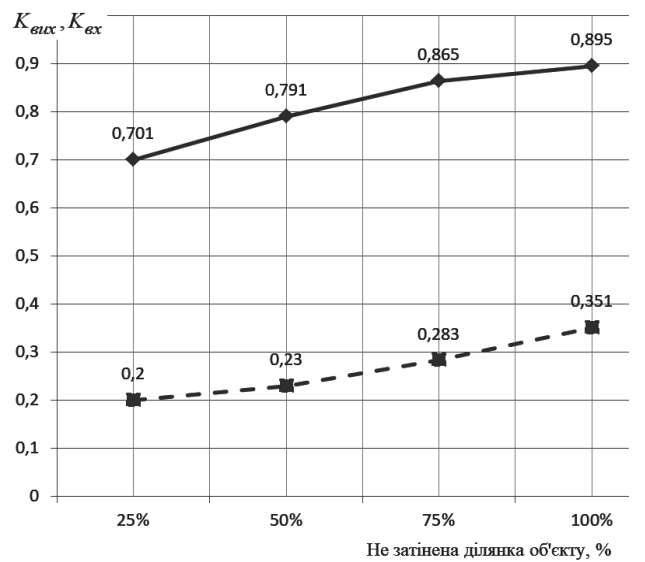

Рис. 10. Графік залежності величини контрасту об'єкту від розміру його поверхні,

що спостерігається, у відсотках до фільтрації зображення $K_{b x}$ та після фільтрації зображення

$$
K_{\text {виx }}
$$

Джерело: розроблено авторами.

Показано, що фізична основа будови активних оптико-електронних систем з узгодженою обробкою оптичних сигналів грунтується на тому, що кольорові поверхні мають вибіркову здатність відбивати та поглинати світло різних довжин хвиль.

Розроблена математична модель виявлення затінених об'єктів з використанням активної оптикоелектронної системи 3 динамічною узгодженою спектральною обробкою оптичного випромінювання. Показано, що всі елементи зображення незатінених листям, спектральні характеристики яких відповідають властивостям об'єкту, мають підвищену яскравість. На підставі функціонування розробленої математичної моделі побудовано графік, 3 якого випливає, що при фіксованих значеннях спектральних характеристик об'єкту та фону можливо визначити, як змінюється контраст об'єкту в залежності від величини затінення об'єкту.

\section{Список літератури}

1. Матвеев А. Н. Оптика. Москва : Высшая школа, 1985. 351 с.

2. Manolakis D., Marden D., Shaw G. Hyperspectral image processing for automatic target detection applications. Lincoln Laboratory Journal. 2003. Vol. 14. No. 1. P. 79-113. http://citeseerx.ist.psu.edu/viewdoc/summary?doi=10.1.1.163.733.

3. Купченко Л. Ф., Рыбьяк А. С., Антонов С. Н., Проклов В. В. Обнаружение объектов по спектральным признакам в оптоэлектронных системах с использованием принципов динамической спектральной фильтрации. Прикладная радиоэлектроника. 2011. № 10(1). С. 22-26.

4. Steinvall O., Renhorn I., Ahlberg J., Larsson H., Letalick D., Repasi E., Lutzmann P., Anstett G., Hamoir D., Hespel L., Boucher Y. ACTIM: An EDA initiated study on active spectral imaging. Proceedings of SPIE. 2010. Vol. 7835, 78350C. P. 1-23. https://doi.org/10.1117/12.865041.

5. Johnson B., Joseph R., Nischan M., Newbury A., Kerekes J., Barclay H., Willard B., Zayhowski J. Compact active hyperspectral imaging system for the detection of concealed targets. Detection and Remediation Technologies for Mines and Minelike Targets IV. 1999. Vol. 3710. P. 144-153. https://doi.org/10.1117/12.357002.

6. Тихонов В. И. Оптимальный прием сигналов. Москва : Радио и связь, 1983. 380 с. 
7. Kupchenko L. F., Goorin O. A., Karlov V. D., Ponomar A. V., Rybiak A. C., Natarova A. O. Active electro-optical system with dynamic spectral processing of optical radiation. 8th International Conference on Advaced Optoelectronice and Lasers (CAOL). IEEE, 2019. P. 489-492. https://doi.org/10.1109/CAOL46282.2019.9019458.

8. Kupchenko L. F., Karlov V. D., Rybiak A. C., Goorin O. A., Ponomar A. V. Active electro-optical system of targets detection with dynamic spectral processing of optical radiation. Semiconductor Physics, Quantum Electronics and Optoelectronics. 2021. Vol. 24. No. 2. P. 218-226. https://doi.org/10.15407/spqeo24.02.218.

9. Купченко Л. Ф., Слабунова Н. В., Гурин О. А. Акустооптический процессор в оптико-электронной системе, обеспечивающий динамическую спектральную фильтрацию. Прикладная радиоэлектроника. 2016. № 15(4). С. $359-361$.

10. Купченко Л. Ф., Рыбьяк А. С. Динамическая спектральная фильтрация оптического излучения в оптоэлектронных системах. Электромагнитные волны и электронные системы. 2011. № 16(4). С. 32-43.

11. Прэтт У. Цифровая обработка изображений в 2-х книгах. Т. 1. Москва : Мир, 1982. 310 с.

12. Дуда Р., Харт П. Распознавание образов и анализ сцен. Москва : Мир, 1976. 511 с.

Надійшла до редколегії 20.10.2021

Схвалена до друку 16.11.2021

\section{Відомості про авторів:}

\section{Купченко Леонід Федорович}

доктор технічних наук професор старший викладач Харківського національного університету Повітряних Сил ім. І. Кожедуба, Харків, Україна

https://orcid.org/0000-0002-8599-1944

\section{Худов Геннадій Володимирович}

доктор технічних наук професор

начальник кафедри Харківського національного університету Повітряних Сил ім. І. Кожедуба, Харків, Україна

https://orcid.org/0000-0002-3311-2848

\section{Гурін Артем Петрович}

ад'юнкт

Харківського національного

університету Повітряних Сил ім. І. Кожедуба,

Харків, Україна

https://orcid.org/0000-0002-8536-4924

\section{Риб'як Анатолій Степанович}

кандидат технічних наук

докторант Харківського національного

університету Повітряних Сил ім. І. Кожедуба,

Харків, Україна

https://orcid.org/0000-0002-7922-3690

\section{Information about the authors:}

\section{Leonid Kupchenko}

Doctor of Engineering Science Professor

Senior Lecturer of Ivan Kozhedub

Kharkiv National Air Force University,

Kharkiv, Ukraine

https://orcid.org/0000-0002-8599-1944

\section{Hennadii Khudov \\ Doctor of Engineering Science Professor \\ Head of Department of Ivan Kozhedub \\ Kharkiv National Air Force University, \\ Kharkiv, Ukraine \\ https://orcid.org/0000-0002-3311-2848}

\author{
Artem Hurin \\ Post-Graduate \\ of Ivan Kozhedub \\ Kharkiv National Air Force University, \\ Kharkiv, Ukraine \\ https://orcid.org/0000-0002-8536-4924
}

\author{
Anatoly Rybiak \\ $\mathrm{PhD}$ in Engineering \\ Doctoral Candidate of Ivan Kozhedub \\ Kharkiv National Air Force University, \\ Kharkiv, Ukraine \\ https://orcid.org/0000-0002-7922-3690
}

\title{
АКТИВНАЯ ОПТИКО-ЭЛЕКТРОННАЯ СИСТЕМА ОБНАРУЖЕНИЯ ЗАТЕНЕННЫХ ОБЪЕКТОВ, ИСПОЛЬЗУЮЩАЯ ПРИНЦИПЫ СПЕКТРАЛЬНОЙ СОГЛАСОВАННОЙ ДИНАМИЧЕСКОЙ ОБРАБОТКИ ИЗОБРАЖЕНИЙ
}

\author{
Л.Ф. Купченко, Г.В. Худов, А.П. Гурин, А.С. Рыбьяк
}

В статье рассматриваются приниипы построения бортовой авиационной системы обнаружения затененных объектов на основе активной оптико-электронной системы с динамической согласованной спектральной обработкой оптического излучения, в которой источником излучения служит набор многоспектральных лазерных излучателей. На основании априорных сведений о спектральных характеристиках объекта и фона вычисляется управляющий сигнал для изменения яркости излучения системы лазерных излучателей, таким образом, чтобы уменьшить величину спектральных составляющих сигнала, отраженного от поверхности, принадлежащей фону с минимальным ослаблением интенсивности сигнала, отраженного от объекта. Разработана математическая модель, позволяющая оценить эффективность активной оптико-электронной системы по величине контраста затененных объектов.

Ключевые слова: активная оптико-электронная система, спектральная обработка оптического излучения, обнаружение затененных объектов. 


\section{ACTIVE OPTICAL-ELECTRONIC SYSTEM FOR DETECTING SHADED OBJECTS USING THE PRINCIPLES OF SPECTRAL CONSISTENT DYNAMIC IMAGE PROCESSING}

L. Kupchenko, H. Khudov, A. Hurin, A. Rybiak

The article discusses the principles of constructing an on-board aviation system for detecting shaded objects based on an active optoelectronic system with dynamic matched spectral processing of optical radiation, in which a set of multispectral laser emitters serves as a radiation source. Based on apriori information about the spectral characteristics of the object and the background, a control signal is calculated to change the brightness of the radiation of the system of laser emitters, so as to reduce the value of the spectral components of the signal reflected from the surface belonging to the background with a minimum attenuation of the intensity of the signal reflected from the object. A mathematical model has been developed for detecting shadowed objects using an active optoelectronic system with dynamic matched spectral processing of optical radiation. It is shown that all elements of images not shaded by foliage, the spectral characteristics of which correspond to the properties of the object, have increased brightness Based on the functioning of the developed mathematical model, a graph is constructed from which it follows that at fixed values of the spectral characteristics of the object and the background it is possible to determine how the contrast of the object changes depending on the shading of the object. The aim of the article is to develop the foundations for constructing an aviation active optoelectronic system for detecting a darkened target with dynamic matched spectral processing of optical radiation, which provides an increase in the contrast of the target relative to the background, as well as the development of a mathematical model that makes it possible to assess the feasibility of the system.

Keywords: active optoelectronic system, spectral processing of optical radiation, detection of shadowed objects. 